CORRECTION

\title{
Correction: Absence of Bim sensitizes mice to experimental
} Trypanosoma cruzi infection

Marcela Hernández-Torres, Rogério Silva do Nascimento, Monica Cardozo Rebouças, Alexandra Cassado, Kely Catarine Matteucci, Maria Regina D'Império-Lima, José Ronnie C. Vasconcelos, Karina R. Bortoluci (D, José Maria Alvarez and Gustavo P. Amarante-Mendes (D)

(c) The Author(s) 2021

Cell Death and Disease (2021)12:817; https://doi.org/10.1038/s41419-021-04098-5

Correction to: Cell Death \& Disease https://doi.org/10.1038/s41419021-03964-6, published online 10 July 2021

The original version of this article unfortunately contained a mistake in the Funding section. The correct funding should read: M.H-T. and K.C.M. were recipients of Ph.D. fellowships from the Fundação de Amparo à Pesquisa do Estado de São Paulo (FAPESP - Brazil - 2012/24737-0, 2015/09568-5). M.C.R. received a postdoctoral fellowship from the Coordenação de Aperfeiçoamento de Pessoal de Nível Superior (CAPES - Brazil). This work was supported by grants from FAPESP (2016/24912-7, 2015/20432-8, 2017/25942-0, 2018/15607-1, 2018/25984-7) and from CNPq (408909/2018-8, 303810/2018-1, 308927/2019-2) to G.P.A-M, M.R. D-L, J.R.V., K.R.B. and J.M.A.

The authors apologize for the error. The original article has been corrected.

\begin{abstract}
(c) Open Access This article is licensed under a Creative Commons Attribution 4.0 International License, which permits use, sharing, adaptation, distribution and reproduction in any medium or format, as long as you give appropriate credit to the original author(s) and the source, provide a link to the Creative Commons license, and indicate if changes were made. The images or other third party material in this article are included in the article's Creative Commons license, unless indicated otherwise in a credit line to the material. If material is not included in the article's Creative Commons license and your intended use is not permitted by statutory regulation or exceeds the permitted use, you will need to obtain permission directly from the copyright holder. To view a copy of this license, visit http://creativecommons. org/licenses/by/4.0/.
\end{abstract}

(c) The Author(s) 2021 